\title{
Stand Up Comedy Indonesia as Anecdote Text Learning Media in Senior High School: Study of Critical Discourse Analysis
}

\author{
Ginanjar Arif Wijaya $^{1}$, Sarwiji Suwandi ${ }^{2}$, Sumarwati ${ }^{3}$ \\ ${ }^{123}$ Postgraduate Indonesian Language Education, Education Faculty, Sebelas Maret University, Indonesia \\ ${ }^{1}$ ginanjararifwijaya@gmail.com, ${ }^{2}$ sarwijiswan@yahoo.com, ${ }^{3}$ watik_uns@ymail.com
}

\begin{abstract}
This research is a descriptive qualitative study that examines the relevance of social criticism on Stand Up Comedy Indonesia towards anecdotal text learning in high school. Stand Up Comedy is a form of comedy or comedy that is delivered monologically to the audience. Stand Up comedy is not only an entertaining spectacle, but every material that is aired is criticized or the message delivered. The purpose of this study was to identify the relevance of social criticism on Stand Up Comedy Indonesia towards anecdotal text learning in high school. The data in this study are in the form of a Stand Up Comedy Indonesia video. The primary data source in this study is Stand Up comedy Kompas TV documents and videos on YouTube. While secondary data sources are relevant primary books, international journals, papers, etc. that are needed in the study of theory. The data collection technique in this study is by documentation and literature. The analysis technique used in this study uses qualitative analysis techniques. Because the data obtained are in the form of texts from various different literary sources, a text analysis is needed. The results of this study are three things. 1) The discourse of stand Up comedy academy has the same structure, namely based on the genre of discourse. 2) The schema and discourse sequence of stand Up comedy academy are in accordance with anecdotal texts, namely those that have components of abstract structure, orientation, crisis, reaction and code. The division of structures can be divided into two parts, complete structure and incomplete. 3) The implementation of the results of this study can be used as teaching material at the eleventh grade high school about producing coherent anecdotal texts in accordance with the characteristics of the text made both orally and in writing.
\end{abstract}

Keywords : Stand Up comedy; anecdotal text; discourse analysis; language learning

\section{Introduction}

In general Stand Up Comedy is a joke or comedy performed on stage by someone who throws a series of jokes that last 10 minutes to 45 minutes. And according to the term Stand Up Comedy is a form of comedy or comedy that is delivered monologically to the audience (Nuroho, 2012: 1). Stand Up Comedy actors are usually called comics. These comics provide humorous stories, short jokes, or insinuations in the form of a unique communication style.

Smart stand Up comedy when he has messages, has benefits for those who listen but don't lose the touch of comedy. The intelligence of a comedian is when the content of the material sounds funny, even though he actually has the intentions implied, not just on the surface. Material or joke content in each comic is presented in various styles and models. Most are more touching on intelligence and invitations to change or morally improve the current conditions around, ranging from mild things (such as youth association, strange habits, trends, fashion, film, politics, etc.) for hard things are like social and political criticism.

Stand Up comedy is not only an entertaining spectacle, but every material that is aired is criticized or the message delivered. The ability to concoct the words of comics to talk and 
joke in front of many people is extraordinary. Stand Up comedy is a smart comedy event, because it requires high creativity from a comic to create alternative logic from the issues discussed. Stand Up Comedy can be used as a very effective media in conveying messages, when we want to criticize something that is wrong, of course we want people to be able to accept what we say. The existence of this program has an influence on public thinking, because the themes discussed are related to everyday life, starting from social, political, cultural, educational, and so on.

Almost the same as Stand-Up comedy, a funny anecdote is the text, character and therein contain constructive criticism. Some experts suggest anecdotal notions such as Keraf (1991: 142) say that anecdotes are a kind of short story that aims to convey interesting or strange characteristics about someone or something else. The anecdote can be interpreted as a short story with character and in it contains constructive criticism. It can also be interpreted as a funny story that aims to criticize someone or something. Likewise Ministry of Education and Culture (2013: 194) states that anecdotes are a type of text that contains funny, ridiculous, or annoying events as a result of a crisis that is responded to with a reaction. Anecdotes are a type of text in which the story shows funny, ridiculous, and insinuating events. From the understanding that has been described, anecdotes are funny stories and in the story there is a satire. The author concludes that anecdotes are funny stories of character and in them are constructive criticisms.

Anecdotal text writing activities must apply the writing structure well according to the predetermined to arrangement, anecdotal text writing has an anecdotal structure in the form of stories or short narratives. According to Kosasih (2014: 19) states that in anecdotal stories there are characters, lines, and backgrounds. The three story structures that must exist in anecdotal text.

In writing anecdotal texts, we must pay attention to the structure that has been established, as explained above that the structure of the anecdotal text must be in the form of a short story or dialogue and have characters, settings and events. As with the Ministry of Education and Culture (2013: 194), the text structure is anecdotal as follows.

a) Abstract: It is a sign of what is told in the form of an unusual event, unusual, strange or in the form of a summary of what the text will tell or explain;

b) Orientation: Introduction or opening in the form of introduction of character, time and place;

c) Crisis: the appearance of a problem;

d) Reaction: A rare action taken to respond to a problem

e) Coda: Changes that occur in characters and lessons that can be learned from the story

From the anecdotal text structure that has been explained about abstraction, orientation, crisis, reaction, and code, it is a unified whole in writing anecdote text. The author concludes that in anecdotal text writers must use appropriate and predetermined structures such as cues, emergence of problems, and truth must be contained so that they can be used as lessons for audiences.

\section{Research Methods}

This research is a descriptive qualitative study with literature study and is not tied to the place of research. Based on the purpose of this study the author uses descriptive methods which include the type of documentary analysis or often referred to as content analysis 
(content analysis). Because trying to describe conclusions from the results of analysis of documents are the object of research. The approach used in this study is a qualitative approach, namely an approach that does not use quantitative efforts or statistical calculations but rather emphasizes the study of interpretation. Research with a qualitative approach (Qualitative Reaseach) is intended to describe and analyze phenomena, events, social activities, beliefs, people's thoughts individually or in groups. Bogdan and Taylor in LJMoleong (2006: 4) defines that qualitative methods are research procedures that produce descriptive data in the form of written or oral words from people and observable behavior.

The data in this study are in the form of a Stand up Comedy Indonesia video. Then the data source according to Moleong (2007: 48) in the form of primary data sources and secondary data sources. The primary data source in this study is Stand up comedy Kompas TV documents and videos on YouTube. While secondary data sources are relevant primary books, international journals, papers, etc. that are needed in the study of theory. Data collection techniques in this study using two methods, namely documentation and literature. To verify the data in this study, the researchers used a triangulation strategy. Triangulation is a process of collecting data which is a combination of various sources and existing data collection techniques. Triangulation according to Creswell (2010: 286) is a technique of collecting different data sources by examining the evidence originating from these sources and using it to build a justification of themes coherently. In this study, the validity examination technique was divided into four types, namely source triangulation, data triangulation, method triangulation, and theory triangulation (Moleong, 2007: 33)

\section{Results and Discussion}

This study examines 30 data and the findings found in "Stand Up" comedy discourse text in Indonesia have the same text elements as anecdotal text elements. The text elements found in the data have a complete and incomplete structure. The research results from 30 Stand Up comedy discourse data from Youtube found 8 data with complete text elements and 22 data with incomplete text elements.

The text structure has incomplete and can text components analyzed according to the components of the text structure as follows.

\begin{tabular}{|c|l|}
\hline Abstraction & $\begin{array}{l}\text { Lots of music boyband so that many teenagers today don't like dangdut } \\
\text { (paragraph 1). }\end{array}$ \\
\hline Orientation & $\begin{array}{l}\text { Dangdut is popular music from the upper to the lower classes, and even extends } \\
\text { abroad (paragraph 2). }\end{array}$ \\
\hline Crisis & $\begin{array}{l}\text { The peanut iwak dangdut sung by Americans becomes crakrer fish (Paragraph 3). } \\
\text { dangdut soneta group becomes the sayonara group (Paragraph 4). }\end{array}$ \\
\hline Reaction & - \\
\hline Koda & - \\
\hline \multicolumn{2}{|c|}{ The researcher conducted research on Stand Up comedy discourse by taking 30 }
\end{tabular}

data. The data is classified into two, namely complete and incomplete structures. The text structure is classified based on the contents of the discourse. Stand up comedy discourse It was found that there were 8 data which had a sticky structure, namely data $3,6,7,8,9,11,14$ and 30. For example, data 6 was analyzed as follows. 


\begin{tabular}{|c|c|}
\hline $\begin{array}{c}\text { Structure } \\
\text { Component }\end{array}$ & Paragraph \\
\hline Abstraction & $\begin{array}{l}\text { Assalammualaikum warohmatullohi wabarokatuh. Thanks Ms. Soimah, thanks a } \\
\text { lot. But before I said Radit, I was confused by Ms. Soimah. Ma'am Soimah told } \\
\text { me to say something about it. Then given a million dollars. Yes, you can get } \\
\text { money, but you know people are sinful. Responsibility is hereafter. So I'm } \\
\text { confused, actually, how come you want to give me money? or want to enter me to } \\
\text { hell? And I'm not lazy, I've found Radit here, cook when I die again with } \\
\text { him. After all, Sis, why are I doing a dozen, Miss. Ma'am, I am afraid of loneliness } \\
\text { there, there is a bang radit! }\end{array}$ \\
\hline Orientation & $\begin{array}{l}\text { I was told to say nothing, this is a serious one. Yesterday because I } \\
\text { mock bang radit, rubbish! I directly on WhatsApp with my mama. } \\
\text { " Yeah, sorry, Bang Bang !" I was told to apologize, this might be because the } \\
\text { women were not brave. So I was suspicious, lest her mother be like that. Every } \\
\text { time you remember me, he is WhatsApp. } \\
\text { " Radit, let's get even crueler, I'm sure you can." }\end{array}$ \\
\hline Crisis & $\begin{array}{l}\text { And just gagging my mom, why am I like that too, I remember how many times, I } \\
\text { was cursed with him This is me confused, Every time I know it, I get scolded.This } \\
\text { is exactly what your child is? Lo, my daddy's daughter, bro? We are brother or } \\
\text { sister? Or maybe we are the swapped sons, but I think, I am the younger brother } \\
\text { and sister. Because I think, I have a lot in common with him. } \\
\text { First, we are both today's young female idols. Radit, if the girls go straight } \\
\text { (screaming) hysterically, I'm going straight for the girls (screaming like } \\
\text { possessions), kumahasiah (Java language means "what's matter?"). Be } \\
\text { mystical. And I tell you, sir, that the vacation is always to Thailand. I don't know } \\
\text { what the impression is, but after I read it, in Thailand there were only } 3 \\
\text { attractions. First shopping, he doesn't like it. Second is beaches, he also doesn't } \\
\text { like it. And the third is the ladyboy that might be the one you like. How are } \\
\text { you? good? And this guy, he's a filmmaker, he's the one who wrote the screenplay, } \\
\text { he's the director, he's the actor. Whether it's multitalent, whether it's greedy. I also } \\
\text { don't know. But we are just positive, maybe we will take all of it because it will be } \\
\text { a bit costly. And I'm confused. I was confused when I was given the story. He is a } \\
\text { guy. Must be lust. But why? In all the films that he made there aren't any funny } \\
\text { scenes, right. He can make what he wants and fight girls. The opponent is } \\
\text { beautiful. Franda, Eriskarin, Kimberly, Bopak, Bolot, Mali, Saipul Jamil. Gag } \\
\text { there is an animated scene. Even though, if he made it because of all the } \\
\text { people. All professional players will want and the boys want to be very intimate } \\
\text { with Kimberly. This is radit, there is a chance, for the video game, it's even } \\
\text { wasted. If I were lo, I made a movie, all the scenes, intimate scenes. Breakfast } \\
\text { hugs, coffee hugs, lunch hugs, strong tile hugs, drive car hugs, ticket hugs. It's all a } \\
\text { hug scene, I'm acting wrong, I'm wrong, so that for the rest of my life I don't run } \\
\text { around }\end{array}$ \\
\hline Reaction & $\begin{array}{l}\text { And anyways, why isn't there an animated scene? Why? Lo, it's not cool, it's } \\
\text { almost ugly, but it's not bad. The girls still want to hug you. It's just a difficult } \\
\text { one. Kimberlykan high, flat radit. If the hug is not good, the waist hug, Kimberly } \\
\text { the hug (the hug scene) the bar is over, so because in all the films that don't have } \\
\text { any romantic scenes, I'm suspicious lest, Actually the radio doesn't like girls. } \\
\text { During this time he was dating just so he was not married. And so he likes to } \\
\text { Thailand, lots of ladyboys. }\end{array}$ \\
\hline Koda & Bang, are we honest with all of us, are you bang? Already honest. We all want to \\
\hline
\end{tabular}




\begin{tabular}{|l|l|}
\hline & $\begin{array}{l}\text { be bang. No, it won't be isolated, at least Bang abdel is immediately ransacked. } \\
\text { Radit, radit, aware of the radar, Astagfirullah, astagfirullah. Raise the person not } \\
\text { expressive. While he was getting rukiyah, he only showed expressive plain. Radit } \\
\text { is ravaged, the cave is burned. Thank you }\end{array}$ \\
\hline
\end{tabular}

The text structure has a complete text structure component and in accordance with the text structure of the 2013 curriculum anecdote, so the table above can be explained as follows.

\begin{tabular}{|c|l|}
\hline Abstraction & $\begin{array}{l}\text { Yuda introduced the initial problem he did a Stand Up comedy "Mbak Soimah told } \\
\text { me to mess with Radit" } \\
\text { (Paragraph 1). }\end{array}$ \\
\hline Orientation & $\begin{array}{l}\text { Yuda explained that he and Radit were different in carrying out bullying } \\
\text { (paragraph 2). }\end{array}$ \\
\hline Crisis & $\begin{array}{l}\text { The difference of opinion of Yuda's parents to what Yuda did with what Radit did } \\
\text { (Paragraph 3). } \\
\text { Yuda has similarities with Radit and Radit's love problems (paragraph 4). } \\
\text { Yuda still bullied Radit's height and Radit's scene in producing films (paragraph 5) }\end{array}$ \\
\hline Reaction & $\begin{array}{l}\text { Raditya Dika laughs because he is still said to be ugly who is insinuated about his } \\
\text { love (paragraph 6). }\end{array}$ \\
\hline Koda & $\begin{array}{l}\text { Radit was told to be honest with the situation that had taken place and Yuda would } \\
\text { accept everything (paragraph 7). }\end{array}$ \\
\hline
\end{tabular}

In addition to the complete text structure, from analyzed 30 data the researchers also found an incomplete text structure. The incomplete text structure consists of 10 data that do not have a coded structure component (changes that occur in characters in the text), 10 data that do not have a component of reaction structure (solving problems that arise in crisis situations) and (changes that occur in characters in the text), 1 data that does not have a orientation and code structure component, and 1 data that does not have a component of orientation structure (background of occurrenceof an event or event that occurs in the text). Text structures that do not have a component of a code structure that is data 2 can be analyzed as follows.

Text "Cikarang City" does not have a section discussed changes to the figures, so that it can be explained as follows.

\begin{tabular}{|c|l|}
\hline Abstraction & $\begin{array}{l}\text { Cikarang city that is very difficult to get along with, is different from the bustling } \\
\text { Jakarta (Paragraph 1). }\end{array}$ \\
\hline Orientation & $\begin{array}{l}\text { Cikarang many entertainment from theaters that have many films, and mall buildings } \\
\text { everywhere, in contrast to the City of Cikarang (paragraph 2). }\end{array}$ \\
\hline Crisis & $\begin{array}{l}\text { Cikarang only has one cinema and has citizens with high integrity. And Cemen does } \\
\text { not deserve to be the brother of mpok Cikarang. Because he deserves to be a brother } \\
\text { and sister (Paragraph 3). }\end{array}$ \\
\hline Reaction & $\begin{array}{l}\text { Asking the audience, do you understand Cikarang ? Then the city of Cikarang is a } \\
\text { labor city (paragraphs 4 and 5). }\end{array}$ \\
\hline Koda & - \\
\hline
\end{tabular}

The text structure that does not have a component of reaction structure and code, which is found in data 1 (Text 1: Dangdut Goes International ) can be seen as follows. 


\begin{tabular}{|c|l|}
\hline $\begin{array}{c}\text { Structure } \\
\text { Component }\end{array}$ & \multicolumn{1}{|c|}{ Paragraph } \\
\hline Abstraction & $\begin{array}{l}\text { Assalammualaikum Warohmatullahi Wabarokatuh. For your information. So } \\
\text { boyband members can't be confused. If you're upset when introducing personnel it } \\
\text { can be chaotic. Hi, I'm Ivory, I'm Martin, I'm ra popo (expression of pity). During } \\
\text { Boyband music, many young people prefer boyband than Indonesian music, for } \\
\text { example dangdut. }\end{array}$ \\
\hline Orientation & $\begin{array}{l}\text { Many embarrassed people like dangdut, even though dangdut according to me is cool } \\
\text { music, popular music, can be enjoyed from all the lower classes to the upper } \\
\text { class. Even dangdut has penetrated overseas. How cool, really cool, isn't it? Dangdut } \\
\text { to America. }\end{array}$ \\
\hline Crisis & $\begin{array}{l}\text { Dangdut to America! How is that? In Indonesia there are Trio Tigers, in America } \\
\text { there may be a Tiger Trio. The singles are not iwak peers, but } \\
\text { Crakrer Fish. Isn't it delicious like that? What's the song? } \\
\text { The Cracker Fish is sung, } \\
\text { Crakrer Fish Crakrer Fish } \\
\text { Risesweet Popcorn } \\
\text { Open Little Joss } \\
\text { Not only until America, dangdut even to Japan. Busyeet, until Japan. This is if in } \\
\text { entering Pop, Japan has AQB 48, and there is a sister group called JKT 48. This is } \\
\text { the dangdut opposite, Indonesia has Sonnet Group, in Japan there may be brother } \\
\text { gruop, the name is Sayonara group. Sing a Sonnet song in Japanese. } \\
\text { Oyasumi oyasumi manohara } \\
\text { Uchiha Sasuke brobate } \\
\text { Aitakata nobita AAAA } \\
\text { Doraemon } \\
\text { (sonnet song entitled 'young blood' }\end{array}$ \\
\hline Reaction & - \\
\hline Koda & -
\end{tabular}

In the text structure it has an incomplete structure. Because in this case it only explains the structure of the crisis. Structure in text this can be explained as follows.

\begin{tabular}{|c|l|}
\hline Abstraction & Lots of music boyband made many teenagers today don't like dangdut (paragraph 1). \\
\hline Orientation & $\begin{array}{l}\text { Dangdut is popular music from the upper to the lower classes, and even extends } \\
\text { abroad (paragraph 2). }\end{array}$ \\
\hline Crisis & $\begin{array}{l}\text { The peanut iwak dangdut sung by Americans becomes crakrer fish (Paraggaf 3). } \\
\text { The dangdut soneta group becomes the sayonara group (Paragraph 4). }\end{array}$ \\
\hline Reaction & - \\
\hline Koda & - \\
\hline
\end{tabular}

The text structure that has been analyzed can be used as teaching material for students class X. The text structure of Indonesian stand up comedy is feasible to be made teaching materials are data that have a complete structure. Amount of data that has the complete structure is 8 data. Of the 8 data that is feasible to be made Indonesian learning materials are data $6,7,8,9,14$, and 30 . Structure the text data is worthy of being used as teaching material because the data has the choice of words that corresponds to high school students of class X. the language used also easy to understand for high school students of class X.

Producing anecdotal texts is one of KD (Basic Competence) the 2013 class $\mathrm{X}$ curriculum in Basic Competence 4.2 produces anecdotal text, reports on observations, complex procedures, and coherent negotiations accordingly 
with the characteristics of the text made both orally and in writing. Implementation What was done in this study was the Indonesian stand up comedy program as one of the learning topics that was used as one how to produce class $\mathrm{X}$ anecdotal text.

\section{Conclusions and Suggestions}

Based on this research can be drawn the conclusion that we can Stand Up in Indosiar has a structure the same text as text structure 2013. The structure of anecdotes curriculum is divided into two structures are complete and incomplete structures. From 30 The oral discourse of data, structured data consists of 8 full and 2 second structured data is incomplete. Rsebut te text structure will be easy to use way to change the discourse dengan14 san li be written discourse with a language that is easily understood.

The manifestation of the stand up comedy academy in Indosiar is that it can be seen from a complete and incomplete structure. Complete structure has complete structural components such as abstracts, informations, crisis, reaction, and code. An incomplete structure can be divided into four, namely parts that do not have a component of the code structure, reaction and code, orientation and code, and orientation. From 30 data, incomplete structure has 22 data which consist of 9 data does not have code compound, 10 data do not have reaction component and code, 2 data does not have orientation and code components, and 1 data does not have orientation component.

The stand up comedy academy can be used as teaching material Indonesian language learning in the production of high school text anecdotes in class X. The amount of data that has an advanced structure is 8 data. Of the 8 data that are suitable to be used as teaching materials for learning Indonesian Language are data 6,7,8,9,14, and 30. The text structure of the data is suitable to be used as material only because the data has a choice of words that are suitable for class $\mathrm{X}$ high school students the language used is also easy to understand students $X$. producing a high school grade anecdotes text contained in the curriculum in 2013, producing 4.2 Competency basic text of anecdotes, reports the results of observations, procedure complex and coherent negotiations in accordance with the characteristics generated captions oral and written, students are required to make an anecdotal text. Students can make funny anecdotal texts. The thing that must be considered is to choose funny and up-to-date topics, take funny words, and not include pornographic elements.

\section{References}

Creswell, J. W. (2010). Research design: pendekatan kualitatif, kuantitatif, dan mixed. Yogjakarta: PT Pustaka Pelajar.

Kemendikbud. 2013. Buku Siswa Bahasa Indonesia Kelas X Ekspresi Diri dan Akademik. Jakarta: Kemendikbud.

Keraf, Gorys. 1991. Argumentasi dan Narasi. Jakarta: Gramedia.

Kosasih, E. 2014. Jenis-jenis Teks (Analisis Fungsi, Struktur, dan Kaidah serta Langkah Penulisannya). Bandung: Yrama Widya.

Moleong, Lexy J. 2007. Metodologi Penelitian Kualitatif. Bandung : Remaja Rosdakarya

Nugroho, Panji. 2012. Potret Stand Up Comedy. Yogyakarta: Pustaka Baru. 